\title{
Solar Car Lift Jack
}

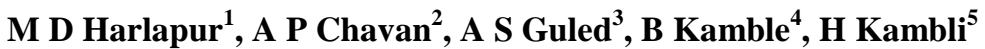 \\ Assistant Professor, Department Mechanical Engg, Rural Engg College, Hulkoti, India ${ }^{1}$ \\ Student, Department Mechanical Engg, Rural Engg College, Hulkoti, India 2,3,4,5
}

\begin{abstract}
This project work titled "Solar Car Lift Jack" has been conceived having studied the difficulty in lifting the any type of light vehicles. Our survey in the regard in several automobile garages, revealed the facts that mostly some difficult methods were adopted in lifting the vehicles for reconditioning. The solar panel is used to charge the car battery. Now the project has mainly concentrated on this difficulty, and hence a suitable device has been designed. Such that the vehicle can be lifted from the floor land without application of any impact force. The fabrication part of it has been considered with almost case for its simplicity and economy, such that this can be accommodated as one of the essential tools on automobile garages.
\end{abstract}

Keywords: Solar, Jack, Lifting, Car.

\section{INTRODUCTION}

Screw type mechanical jacks were very common for - Wind Power Method jeeps and trucks of World War II vintage. For - Bio Mass Method example, the World War II jeeps (Willys MB and - Wave Energy Method Ford GPW) were issued the "Jack, Automobile, Screw - Ocean Power Method type, Capacity 1 1/2 ton", Ordnance part number 41J-66. This jacks, and similar jacks for trucks, were activated by using the lug wrench as a handle for the jack's ratchet action to of the jack. The 41-J-66 jack was carried in the jeep's tool compartment. Screw type jack's continued in use for small capacity requirements due to low cost of production raise or lower it. A control tab is marked up/down and its position determines the direction of movement and almost no maintenance.

This device the solar car lift jack for automobile garages has been developed to later the needs of small and medium automobile garages, who are normally man powered with very minimum of skilled labours. In most of the garages the vehicles are lifted by using screw jack. This needs high man power and skilled labours. In order to avoid all such disadvantages. This, solar car lift jack has been designed in such a way that it can be used to lift the vehicle very smoothly without any impact force. The operation is made be simple that even an unskilled labour can handled, by just demonstrating the working of the solar car lift jack once. The dc motor is coupled with the screw jack by spur gear mechanism. This is an era of automation where it is broadly defined as replacement of manual effort by mechanical power in all degrees of automation. The operation remains an essential part of the system although with changing demands on physical input as the degree of mechanization is increased.

\section{METHODS OF UTILISATION OF SOLAR ENERGY}

DIRECT METHOD OF UTILIZATION OF SOLAR ENERGY:

The most useful way of harnessing solar energy is by directly converting it into electricity by means of solar photo-voltaic cells. Sunshine is incident on Solar cells, in this system of energy Conversion that is direct conversion of solar radiation into electricity.

In the stage of conversion into thermodynamic from is absent. The photo-voltaic effect is defined as the generation of an electromotive force as a result of the absorption of ionizing radiation. Energy conversion devices, which are used to convert sunlight to electricity by use of the photo-voltaic effect, are called solar cells.

In recent years photo-voltaic power generation has been receiving considerable attention as one of the more promising energy alternatives. The reason for this rising interest lie in PV's direct conversion of sunlight to electricity, the non-polluting nature of the PV widespread are of PV generation has been hampered by economic factors. Here to force, the low cost of conventional energy sunlight has obviated the development of a broad-based PV technology. At the present time, PV generation can be justified only for special situations mostly for remote sites where utility lines on other conventional means of furnishing energy may be prohibitively expensive and is one of the most attractive non-conventional energy sources of proven reliability from the micro to the Mega-watt level.

PHOTO VOLTAIC METHOD AND PHOTOVOLTAIC PRINCIPLES:

- Photo Voltaic Method

- Thermal Method

The photo-voltaic effect can be observed in nature in a variety of materials that have shown that the best performance in sunlight is the semiconductors as stated INDIRECT METHOD

- Water Power Method above. When photons from the sun are absorbed in a 
semiconductor, that create free electrons with higher energies than the created there must be an electric field to induce these higher energy electrons to flow out of the semi-conductor to do useful work. A junction of materials, which have different electrical properties, provides the electric field in most solar cells.

To obtain a useful power output from photon interaction in a semiconductor, three processes are required. The photon has to be absorbed in the active part of the material and result in electrons being excited to a higher energy potential.

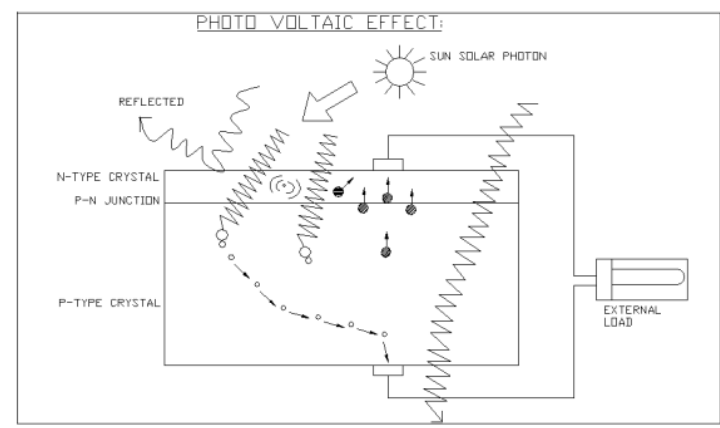

Fig-1; Photo Voltaic Effect

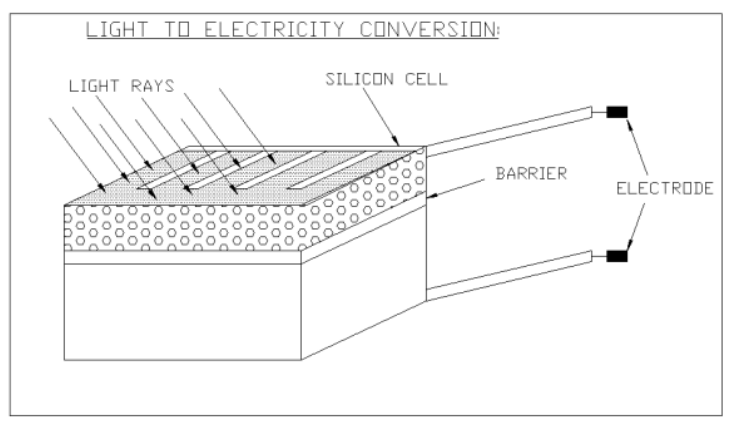

Fig-2; Light to Electricity Conversion

\section{III.CONSTRUCTION AND FABRICATION}

The construction of the photo-voltaic cell is also known as the barrier layer or rectified cell as shown in figure. It consists of a base plate made of either steel or aluminium and carries a layer of metallic selenium, which is light sensitive. An electrically conducting layer of cadmium oxide is applied by sputtering over the silinium layer.

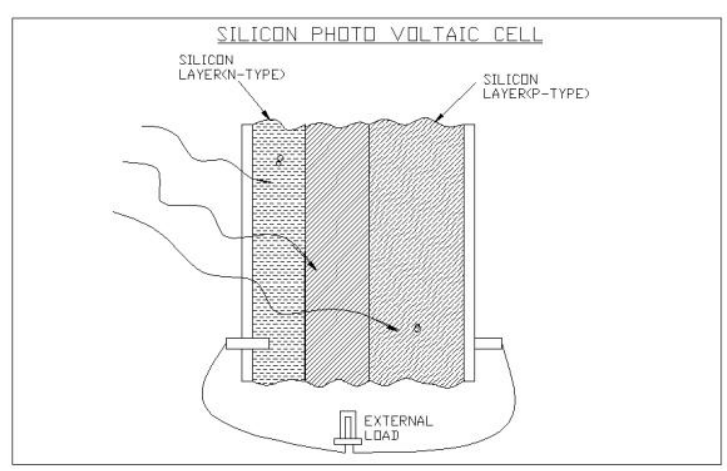

Fig-3; Silicon photo voltaic cell

The layer is sufficiently thin to allow light to reach the silinium and is electrically continuous as it acts as the negative pole. The negative contact is formed of a strip of woods metal sprayed on to the edge of the top surface. The base plate forms the positive contact. A transparent varnish protects the front surface of the cell. When light falls on the upper surface of the selenium, electrons are released from the surface, which maintained a flow of current through the external circuit connected between the positive and negative contacts.

In the current output of a photocell should be proportional to the illumination, which is achieved by keeping the external resistance at a low value. Also if greater accuracy is required then illumination should not be allowed to exceed 25 lumens/feet ${ }^{2}$. The smaller the size of the cell, of course compatible with obtaining sufficient current to be properly measured, the better a linear relation is obtained between current and illumination. This is because, for such a cell, the resistance of the electrically conducting film is at minimum. Also, since the current is small, the voltage drop due to the circuit resistance will be kept low. Limitation of the photocell is that if the light is incident at the angels of $60^{\circ}$ or above, the lacquer tends to reflect a significant an amount of light which, therefore, does not reach the selenium layer.

Thus the current is less than what it should be according to cosine law of illumination. Using a Matt lacquer can make some compensation for this. A better method is to omit the lacquer and cover the cell with a hemispherical dome of transparent plastic. The equivalent circuit of a photo-voltaic cell is shown in figure-3.

Here $\mathrm{E}$ is a perfect photo-voltaic generator, which produces a current proportional to the illumination.

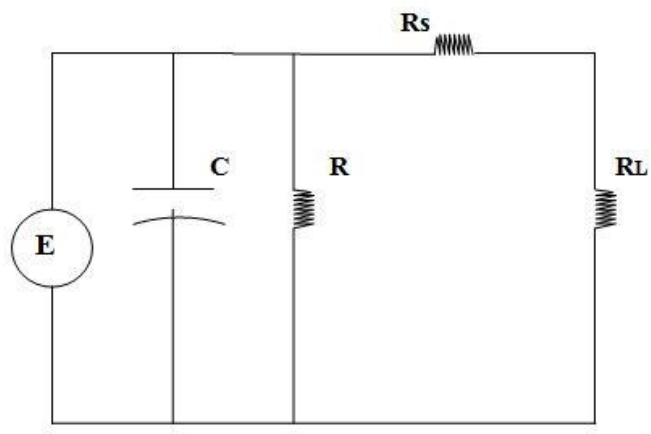

Rs $=$ Series resistance,

$\mathrm{C}=$ the effective capacitance,

$\mathrm{R}=$ the equivalent of the barrier layer resistance

$\mathrm{RL}=$ the resistance of external circuit.

Apart from the differences in the nature of the semiconductor used, the following different cell configurations have been used:

(1) p-n homo junction

(2) p-n hetro junction

(3) Schotty barrier

(4) Homo junction hetro structure

(5) MIS (metal insulator-semiconductor cell)

Above 17 distinctly different types of solar systems having AMI solar energy conversion efficiencies in excess of 5 percentages have been reported in TABLE 1. of these, 
nine have efficiencies in excess of 10 percentages. Three semi-conductor, silicon, gallium arsenide and cadmium sulphide are constituents of 15 of these cells of the remaining three cells, two contain cadmium telluride as principle constituents, and the other contains indium phosphate.

Over $95 \%$ of cells in commercial production are silicon $\mathrm{p}$ $\mathrm{n}$ junction while consumer items are now using amorphous Si-pn cells. While the former has been used in space ventures and in terrestrial PV arrays generating $1 \mathrm{MW}, \mathrm{a}-\mathrm{Si}$ cells are used under low illuminating intensities since they deteriorate under high intensities. Their low-cost advantage is yet to be realised.

In these varieties of cells, we use "MONOCRYSALLINE CELL" for getting the power and its production is been explained below.

Table I Thin Film and Polycrystalline Solar Cell Systems with Ami Solar Energy Conversion Efficiencies In Excess of 5 Percentage

\begin{tabular}{|l|c|c|}
\hline Type of cell & $\begin{array}{l}\text { Semi- } \\
\text { Conductor } \\
\text { Constituents }\end{array}$ & $\begin{array}{l}\text { Highest } \\
\text { Efficiency } \\
\text { \%(Ami) }\end{array}$ \\
\hline $\begin{array}{l}\text { Polycrystalline } \\
\text { Homo-junction } \\
\text { Thin-film } \\
\text { hetro-junction }\end{array}$ & Silicon & $\sim 8$ \\
$\begin{array}{l}\text { Thin-film } \\
\text { hetro-junction }\end{array}$ & $\mathrm{p}-\mathrm{Cu} \alpha \mathrm{S} / \mathrm{n}-\mathrm{Cds}$ \\
$\begin{array}{l}\text { Thin-film } \\
\text { hetro-junction }\end{array}$ & $\mathrm{p}-\mathrm{Cu} 2 \mathrm{Te}_{2} / \mathrm{n}-$ & $\sim 9$ \\
$\mathrm{CdTe}$ & $\mathrm{p}-\mathrm{Cu} \mathrm{In} \mathrm{Se} / \mathrm{n}-$ \\
$\begin{array}{l}\text { Thin-film } \\
\text { amorphous } \\
\text { semiconductor, } \\
\text { scotty barrier }\end{array}$ & $\begin{array}{c}\mathrm{Silicon} \\
\end{array}$ & $\sim 6$ \\
\hline
\end{tabular}

Fabrication of a motorized screw jack is easy especially when the parts are available in the market. This mechanical engineering project can be easily completed by integrating an electric motor with a screw jack.

A screw jack or a Jackscrew is operated by turning a lead screw. The height of the jack is adjusted by turning the lead screw. This can be done either manually or by integrating an electric motor with it. This integration is our project.

The difficult part in the project may be finding a low speed motor that is able to work at $12 \mathrm{~V}$. This is because the battery output of an automobile is $12 \mathrm{~V}$, and the electricity needed for the operation of the screw jack is taken from this battery. Another problem will be regarding speed reduction. $12 \mathrm{~V}$ motors usually operate at higher speeds, likely at 4000 or $5300 \mathrm{rpm}$. So reducing this high rpm to the required lower rpms for the operation of screw jack without bulky accessories or power loss can be challenging. But still this is one of the easiest projects in mechanical.

\section{IV.WORKING PRINCIPLE}

The solar panel is used to charge the car battery. The leadacid battery is used to drive the D.C motor. The D.C motor shaft is connected to the spur gear. If the power is given to the D.C motor, it will run so that the spur gear also runs to the slow speed of the D.C motor. The screw jack and moves the piston upward, so that the vehicle lifts from ground. The vehicle is lifted by using the lifting flat form in the top of the screw jack. The motor is drawn supply from the battery. The lifting and uplifting is done by changing the battery supply to the motor simply.

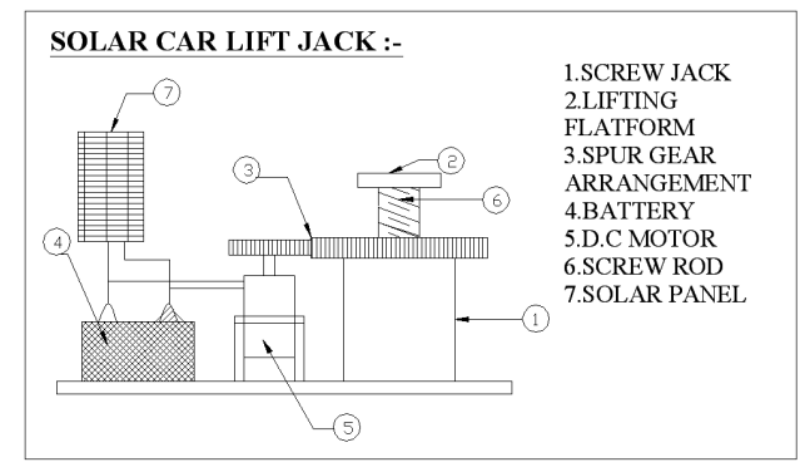

The lead acid battery is used to drive the d.c motor. The d.c motor shaft is connected to the spur gear.

If power is given to the D.c motor, it will run so that the spur gear also runs to slow down the speed of the D.C motor. The screw jack moves the screw upward, so that the vehicle lifts from ground. The vehicle is lifted by using the lifting platform at the top of the screw jack. The motor draws power supply from the battery. The lifting and uplifting is done by changing the battery supply to the motor.

\section{Advantages}

1. The loaded light vehicles can be easily lifted.

2. Checking and cleaning are easy, because the main parts are screwed.

3. Handling is easy

4. No Manual power required.

5. Easy to Repair.

6. Replacement of parts are easy

Disadvantages

1. Cost of the equipment is high when compared to ordinary hand jack.

2. Care must be taken for the handling the equipment such as proper wiring connection, battery charging check-up, etc.

\section{Applications}

1. It is useful in auto garages.

2. This motorized screw jack is used for lifting the vehicles. Thus it can be useful for the following types of vehicles in future; Maruti, Ambassador, Fiat, Mahindra. 


\section{CONCLUSION}

The fabrication of solar car lifting jack was successfully completed as per the designed specification. The trial performance of this device provides to be successful, with case of operation and safety, hence the results has given a clear indication of its commercial viability. The cost analysis has shown its economic feasibility and we are under the impression that it can be further reduced, when produced on a mass scale.

\section{ACKNOWLEDGMENT}

At this pleasing moment of having successfully completed our project, we wish to convey our sincere thanks and gratitude to the management of our college and our beloved chairman who provided all the facilities to us. We would like to express our sincere thanks to our principal for forwarding us to do our project and offering adequate duration in completing our project.

We are also grateful to the Head of Department for her constructive suggestions \& encouragement during our project.

\section{REFERENCES}

[1]. http://en.wikipedia.org/wiki/Jack_(device)http://hubpages.com/hub/ Automobile

[2]. http://www.scribd.com/doc/38577261/Screw-Jack-Design.

[3]. jacks.phphttp://www.powerjacks.com/PowerJacks History-TheScrew Jack

[4]. Design of machine elements by V.B.Bhandari

[5]. A text book of machine design by Rajendra Karwa

[6]. Analysis and Design of Machine Elements by V K Jadon, Suresh Verma

[7]. Tribology in Machine Design by T. A. Stolarski

[8]. A text book of Machine Design by R.S.Khurmi,J.K.Gupta

[9]. Design of Machine Elements by Farazdak Haideri

[10]. Machine Design by S.G.Kulkarni

[11]. Design of machine elements by K.Rao 